\title{
OPA3 gene mutations responsible for autosomal dominant optic atrophy and cataract
}

\author{
P Reynier*, P Amati-Bonneau*, C Verny, A Olichon, G Simard, A Guichet, C Bonnemains, \\ F Malecaze, M C Malinge, J B Pelletier, P Calvas, H' Dollfus, P Belenguer, Y Malthièry, $G$ Lenaers, \\ D Bonneau
}

$\mathrm{H}$ ereditary optic atrophy is a generic term that refers to a heterogeneous group of genetic disorders for which several modes of inheritance have been described. ${ }^{1}$ The most common forms of optic atrophy are autosomal dominant optic atrophy (ADOA, OMIM 165500) and Leber's hereditary optic neuropathy (LHON, OMIM 53500). ADOA, which generally starts in childhood, is characterised by a progressive decrease in visual acuity, blue-yellow dyschromatopsia, loss of sensitivity in the central visual field, and optic nerve pallor.

Mutations in the optic atrophy 1 (OPAl) gene, located on chromosome $3 \mathrm{q} 28-\mathrm{q} 29$, are implicated in about $60-80 \%$ of the cases of ADOA. ${ }^{1-4}$ OPAl encodes for a mitochondrial dynamin related protein. This protein, anchored to the mitochondrial inner membrane, contributes to mitochondrial structure and biogenesis. $^{56}$

A second gene involved in ADOA, not yet identified, has been mapped to chromosome 18q (OPA4, OMIM 605293). ${ }^{7}$ LHON, which is caused by specific mutations in mitochondrial DNA, is inherited maternally. ${ }^{8}$ It is characterised by severe bilateral optic atrophy responsible for acute or subacute visual loss, usually starting between the ages of 18 and 35 .

Other forms of hereditary optic atrophy include X linked optic atrophy (XLAO, OPA2, OMIM 311050$)^{9}$ and autosomal recessive optic atrophy (AROA), for which a first locus has recently been mapped to chromosome 8q. ${ }^{10}$ Finally, more than 15 disorders-mostly inherited in the autosomal recessive mode-have combined optic atrophy and extraocular anomalies. Among these syndromic optic atrophies, type III 3-methylglutaconic aciduria (MGA) (OMIM 258501), also known as the Costeff syndrome ${ }^{11}$ or the optic atrophy plus syndrome, consists of early onset bilateral optic atrophy, later onset spasticity, extrapyramidal signs, and cognitive deficit. Urinary excretion of 3-methyl glutaconic acid and increased plasma 3-methylglutaric acid levels are the hallmarks of MGA. $^{12}$ Linkage analyses, undertaken in MGA families originating from inbred Iraqi-Jewish populations, allowed the mapping of the disease causing gene to chromosome 19q13.2-q13.3, close to the gene responsible for myotonic dystrophy. ${ }^{13}$ The gene responsible for MGA, namely optic atrophy 3 (OPA3), has since been identified. ${ }^{14}$

Until now, only two mutations in OPA3 have been reported in studies covering nine families affected by type III MGA. ${ }^{14}{ }^{15}$ Here we report two missense mutations in OPA3 in two families affected by autosomal dominant optic atrophy and cataract (ADOAC), a disease first described by Garcin et al in 1961 (OMIM 165300). ${ }^{16}$ Our results indicate that OPA3, encoding a protein in the mitochondrial inner membrane, is responsible for autosomal recessive as well as autosomal dominant optic atrophies.

\section{Key points}

- Hereditary optic atrophies form a heterogeneous group of disorders with different modes of inheritance. $O P A 1$, encoding for a mitochondrial protein, is currently the only gene identified in autosomal dominant optic atrophies. OPA3, implicated in autosomal recessive optic atrophy (OMIM 258501), might also be responsible for autosomal dominant optic atrophy.

- OPA3 was directly sequenced as a candidate gene in two unrelated families affected with autosomal dominant optic atrophy and cataract (ADOAC, OMIM 165300). OPA3 was studied in 11 affected individuals and 10 healthy relatives. In addition, OPA3 encodes for a mitochondrial protein of unknown function, possible mitochondrial dysfunction in skin fibroblasts from a patient with ADOAC was investigated.

- Two different mutations in exon 2 of OPA3 were found in patients with ADOAC. The 277G $\rightarrow$ A (G93S) mutation was present in one family, and the $313 C \rightarrow G$ (Q105E) mutation in the other. Both mutations segregated with the disease in each family and were absent in healthy relatives and in 400 control chromosomes. No abnormalities were found in the respiratory chain or in the mitochondrial membrane potential, or in the organisation of the mitochondrial network of the fibroblasts obtained from one affected patient. However, the fibroblasts showed increased susceptibility to staurosporine induced apoptosis.

- The results indicate that OPA3 is responsible for dominant optic atrophy as well as autosomal recessive atrophy. Thus, along with autosomal dominant optic atrophy and Leber's hereditary optic neuropathy, ADOAC is yet another form of hereditary optic atrophy involving a mitochondrial inner membrane protein and a possible apoptotic mechanism.

Abbreviations: ADOA, autosomal dominant optic atrophy; ADOAC,
autosomal dominant optic atrophy and cataract; AROA, autosomal
recessive optic atrophy; LHON, Leber's hereditary optic neuropathy;
MGA, 3-methylglutaconic aciduria; OPA1, optic atrophy 1; OPA3, optic
atrophy 3; XLAO, X linked optic atrophy
*The first two authors contributed equally to this work 


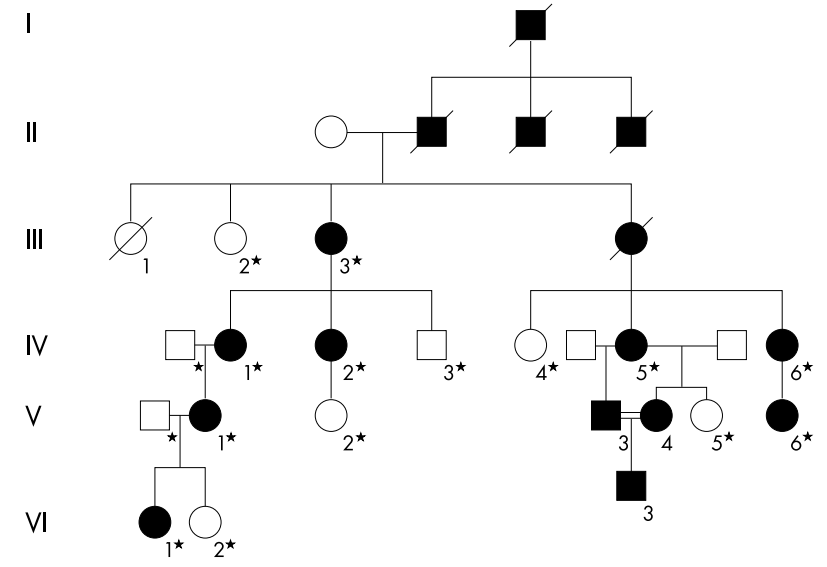

Family 1

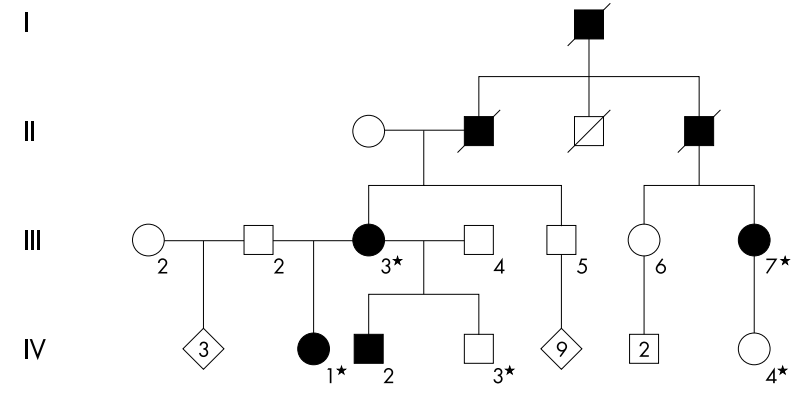

Family 2

Figure 1 Pedigrees of the families affected by autosomal dominant optic atrophy and cataract (ADOAC). Filled symbols = affected; empty symbols $=$ unaffected; square $=$ male; circle $=$ female; star $=$ subjects in whom the OPA3 gene was sequenced.

\section{METHODS}

\section{Clinical report}

Family 1

We re-examined the French family first reported in 1961 by Garcin et $a l^{16}$ in which members belonging to four generations were affected by ADOAC (fig 1).

Patient III.3, a female born in 1920, suffered from a visual impairment from infancy which worsened from the age of 28. At age 38, her visual acuity was $2 / 10$ in both eyes and ophthalmological examination revealed bilateral optic atrophy and posterior cortical cataract. On neurological examination there was resting and postural tremor of both hands and a mild extrapyramidal rigidity of both upper limbs. She had bilateral pes cavus and absence of deep tendon reflexes in the lower limbs. The cataract was operated on at age 51, when her visual acuity was $1 / 10$ in each eye. Neurological examination at age 83 showed the same extrapyramidal signs as before, but there was no worsening of the disease.

Patient IV.1, a female born in 1943, suffered from decreased visual acuity before the age of 10. At age 15, she had a visual acuity of 5/10 in each eye, bilateral optic atrophy, and bilateral posterior cortical cataract. Neurological examination at age 15 showed mild postural tremor, mild rigidity of both upper limbs, and mild bilateral pes cavus. Her visual acuity gradually decreased to $1 / 10$ in both eyes. Cataract lens implant surgery was done at the ages of 47 and 48 . At age 58, she developed bilateral central scotomata. Neurological examination at age 60 showed a mild postural tremor of the upper extremities.

Patient IV.2, a female born in 1945, contracted paralytic poliomyelitis at age 18 months. Her visual acuity first decreased before the age of 10. At age 13, the visual acuity was $3 / 10$ and $9 / 10$ in the right and left eyes, respectively. Fundus examination revealed bilateral optic atrophy, and slit lamp examination showed bilateral anterior cortical cataracts. Cataract lens implant surgery was done at the ages of 45 and 46. Visual acuity was $2.5 / 10$ and 3.2/10 in the right and left eyes, respectively, at age 57. At that age, neurological examination, although difficult because of sequelae of poliomyelitis, showed postural tremor without additional extrapyramidal signs. Magnetic resonance imaging of the brain was normal.

Patient V.1, a female born in 1967, first had a decrease in visual acuity at the age of 12 . At age 18 , visual acuity was $4 / 10$ in each eye. There was bilateral optic atrophy on fundus examination, and slit lamp examination showed bilateral anterior cortical cataracts. Bilateral central scotomata were demonstrated by Goldmann visual field examination. The Farnsworth-Munsell colour vision test revealed a mild redgreen dyschromatopsia. Electroretinography was normal and visual evoked potential (VEP) testing showed a bilateral increase in P2 latency ( 120 to $158 \mathrm{~ms}$ ). Cataract lens implant surgery was undertaken at age 25 . At age 29 , the visual acuity was $2 / 10$ in the right eye and 3/10 in the left eye. Neurological examination was normal.

Patient VI.1, a female born in 1995, was first examined at age three years and eight months for visual impairment. Fundus examination was normal but the slit lamp showed bilateral anterior and posterior subcapsular opacities. Cataract surgery was done at four years of age. Three months after lens surgery, the visual acuity was 7/10 in each eye. Though the fundus appeared pale, it was still considered normal. VEP at age 7 were normal in both eyes. The neurological examination was normal.

Patient IV.6, a female born in 1953, had visual impairment from early infancy. The diagnosis of optic atrophy was made in infancy and she received special education for visually impaired children. She currently has lens opacities but cataract surgery has never been done. She has no neurological signs at age 50 .

Patient V.6, a female born in 1982, has also had visual impairment from early infancy but went through normal schooling. Cataract surgery was done at age 5. Neurological examination was normal at age 5 .

Detailed clinical data are unavailable from the other patients in the same family affected with ADOAC - that is, patients IV.5, V.3, V.4, and VI.3.

\section{Family 2}

Patient III.3, a female born in 1944, suffered a decrease in visual acuity from age 12 . At age 37 , her visual acuity was 1 / 50 with a central scotoma and optic nerve atrophy in each eye. She became legally blind at age 54, and posterior capsular cataract was diagnosed at age 56.

Patient III.7, a female, was born in 1955. Her visual acuity decreased from age 10. Bilateral cataract was diagnosed at age 45 , and she is currently legally blind.

Patient IV.1, a female born in 1971, suffered a decrease in visual acuity from age 6 . At age 9, her visual acuity was 4/10 with a central scotoma and blue-yellow dyschromatopsia in both eyes. Electroretinography was normal. A bilateral cataract was diagnosed at age 10.

Ophthalmological examination at age 33 showed a visual acuity of $0.5 / 10$ in both eyes. Fundus examination revealed bilateral atrophy and temporal pallor of the optic nerve. Slit lamp examination showed bilateral cerulean cataracts (fig 2). Neurological examination was normal.

Patient IV.2, a male born in 1976, was affected by optic atrophy at age 12. At that age, his visual acuity was 3/10 in each eye, and he had bilateral central scotomata and 


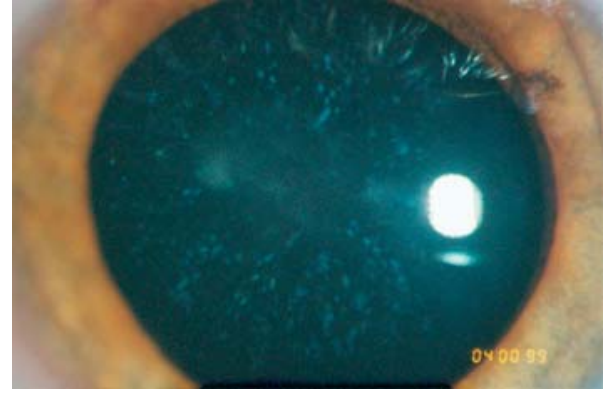

Figure 2 Cerulean cataract observed in patient IV. 1 from family 2.

blue-yellow dyschromatopsia. Surgery for bilateral capsular posterior cataract was done when he was 19.

\section{OPA3 gene sequencing}

Blood samples were obtained from eight affected patients and eight healthy relatives from family $\mathrm{l}$ and three affected patients and two healthy relatives from family 2 .

Genomic DNA was extracted from blood samples using the High Pure polymerase chain reaction (PCR) template preparation kit (Roche Diagnosis, Mannheim, Germany). Four primer couples were used to amplify the two coding exons. ${ }^{14}$ PCR reactions were carried out under standard conditions with $100 \mathrm{ng}$ of genomic DNA in a $50 \mu \mathrm{l}$ volume: $1.5 \mathrm{mM} \mathrm{MgCl} 2,75 \mathrm{mM}$ Tris- $\mathrm{HCl}\left(\mathrm{pH} 9\right.$ at $\left.25^{\circ} \mathrm{C}\right), 20 \mathrm{mM}$ $\left(\mathrm{NH}_{4}\right)_{2} \mathrm{SO}_{4}, 0.01 \%$ Tween $20,50 \mathrm{pmol}$ of each primer, $200 \mu \mathrm{M}$ of each dNTP, and 2 units of Hot GoldStar (Eurogentec, Seraing, Belgium). Each of the 30 cycles consisted of a denaturation step of 30 seconds at $94^{\circ} \mathrm{C}$, a hybridisation step of 30 seconds at $58^{\circ} \mathrm{C}$, and an extension step of one minute at $72^{\circ} \mathrm{C}$. The purified PCR products were sequenced using a Ceq2000 DNA sequencer (CEQ DTCS-Quick Start Kit, Beckman Coulter, Fullerton, California, USA). Multiple sequence alignments were made using CLUSTALW software.

\section{LOD score calculations}

Multipoint LOD score analysis was undertaken in family 1 using markers D3S1601, D3S3669, and D3S2748 at the OPAI locus with the Genehunter computer package under an autosomal dominant model of transmission, with a maximum disease frequency of $1 / 12000,{ }^{2}$ as well as in a nonparametric model.

\section{Biochemical investigations}

The plasma concentrations of lactate, pyruvate, and ketone bodies were assessed by spectrophotometry using commercial kits (Roche Diagnostics, Meylan, France). Urinary organic acids and plasma amino acids were analysed, respectively, by gas and ion exchange chromatography. The activity of the fibroblast mitochondrial respiratory chain was assessed by the polarographic measurement of oxygen consumption and by the determination of the individual activity of the respiratory chain complexes II, III, and IV, according to Rustin et al. ${ }^{17}$

\section{Apoptosis}

Fibroblasts, obtained from patient IV.2 by skin biopsy, were cultured in RPMI 1640, $10 \%$ fetal calf serum, and 5\% $\mathrm{CO}_{2}$. The fibroblasts were exposed to staurosporin at concentrations of 50 or $100 \mathrm{nM}$ over 24 hours. The percentage of apoptosis was calculated from triplicate values obtained in the course of two independent experiments; apoptotic nuclei were identified by the presence of condensed chromatin on DAPI staining. Control fibroblasts were obtained from an unaffected individual and prepared at the same time and in the same way as the patient's cell line.

\section{Mitochondrial membrane potential}

For the analysis of the mitochondrial membrane potential $\left(\Delta \Psi_{\mathrm{m}}\right)$, the fibroblasts were incubated for 20 minutes with 5 $\mu \mathrm{g} / \mathrm{ml} \mathrm{JC-l} \mathrm{(Molecular} \mathrm{Probes,} \mathrm{Leiden,} \mathrm{Netherlands)} \mathrm{in} \mathrm{the}$ culture medium, then collected, washed in phosphate

WT (IV-3)

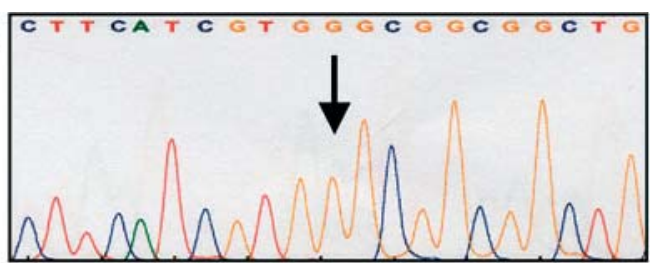

MT (IV-2)

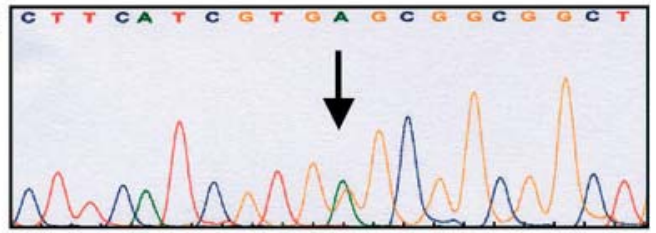

MT (V-1)

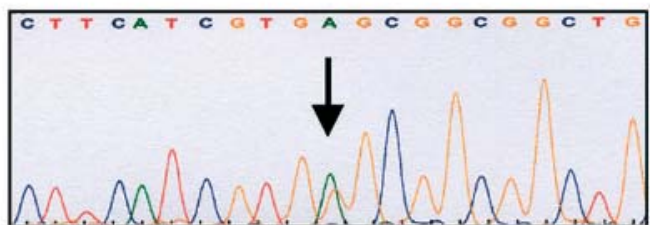

Family 1

WT (IV-3)

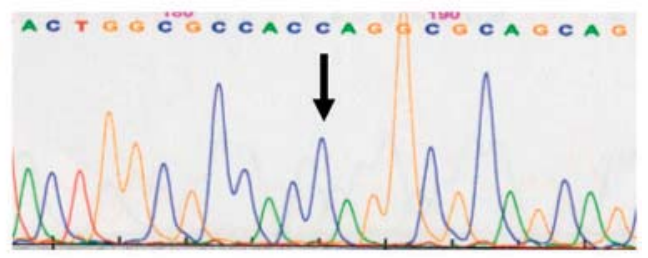

MT (IV-1)

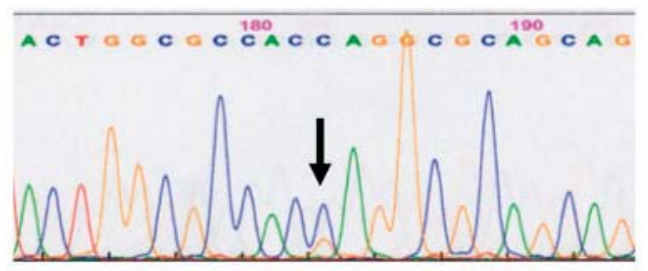

MT (IV-1)

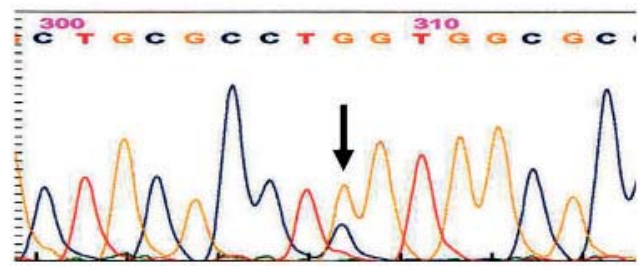

\section{Family 2}

Figure 3 Electropherograms of OPA3 gDNA sequencing showing wild-type (WT) and mutant (MT) sequences in, respectively, healthy (IV3 ) and affected members of family 1 (IV-2 and V-1) and healthy (IV-3) and affected member (IV-1) of family 2. Direct and reverse sequences are given for patient IV-1 of family 2 . 


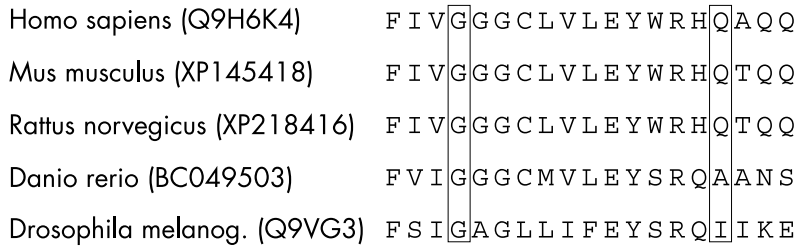

Figure 4 Amino acid alignments of different orthologs of OPA3 genes (Clustal W 1.82). The box shows the amino acid conserved in all five species.

buffered saline (PBS), and processed for fluorescence analysis on an Ascent Fluoroscan using the Ascent Software (excitation $488 \mathrm{~nm}$; emission $538 \mathrm{~nm}$ and 590 $\mathrm{nm}$ ). The ratio of the fluorescence at $590 \mathrm{~nm}$, proportional to the $\Delta \Psi_{\mathrm{m}}$, to that at $538 \mathrm{~nm}$, proportional to the mitochondrial mass, was calculated from triplicate values obtained in the course of two independent experiments.

\section{Mitochondrial network}

Cells grown on glass coverslips were stained directly in the culture using $100 \mathrm{nM}$ CMXros Mitotracker ${ }^{\circledR}$ Red (Molecular Probes) for 30 minutes, then fixed and DAPI stained in PBS, $3.7 \%$ paraformaldehyde $\left(30\right.$ minutes, $4^{\circ} \mathrm{C}$ ). Fluorescence images were captured and processed using a Leica DMIRE2 microscope.

\section{RESULTS}

Families 1 and 2 relate to a group of 25 families affected by dominant optic atrophy for which negative results in sequencing OPAl had previously been obtained in our laboratory. Furthermore, the OPAI locus was excluded by linkage analysis in family 1 on the basis of a significantly negative LOD score of -4.83 at $\theta=0$. The OPA3 gene was subsequently studied in both families with reference to a candidate gene.

We found two novel missense mutations in exon 2 of the OPA3 gene-namely, the $277 \mathrm{G} \rightarrow \mathrm{A}$ (G93S) mutation in all affected members from family 1 , and the $313 \mathrm{C} \rightarrow \mathrm{G}$ (Q105E) mutation in those of family 2 (fig 3 ). In both families, the mutations segregated with the disease and were absent in healthy relatives as well as in 400 control chromosomes. Both these mutations of the OPA3 gene involve strongly conserved residues in the OPA3 orthologs of different species (fig 4).

No abnormalities of the respiratory chain (data not shown), the mitochondrial membrane potential (fig 5), or the morphology of the mitochondrial network (fig 6) were found in fibroblasts from patient IV.2 from family 1. Lactataemia and urinary concentrations of 3-methylglutaconic and 3-methylglutaric acids were not increased in patient

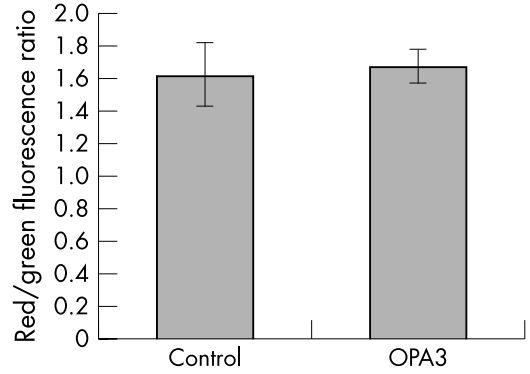

Figure $5 \Delta \Psi_{m}$ assessment with JC-1 dye in fibroblasts from patient IV-2 (family 1) versus control fibroblasts.

IV.2 (data not shown). Nevertheless, an increased susceptibility to the induction of apoptosis was observed in cultured fibroblasts treated with staurosporin. Indeed, an average of $35 \%$ of apoptotic cells was found in the fibroblasts of the affected individual, versus 5\% in controls (fig 7).

\section{DISCUSSION}

We report here the molecular basis of an autosomal dominant disorder referred to as optic atrophy, cataract, and neurological disorder in the OMIM database (165300), first described by Garcin et al in 1961. ${ }^{16}$ Although these investigators described the disease as a neurodegenerative disorder and discussed a possible relation to Friedreich's ataxia, the neurological signs are mild or even absent in affected patients. Thus the disease could be more appropriately designated as autosomal dominant optic atrophy and cataract (ADOAC).

ADOAC is caused by a mutation in the OPA3 gene, known to be involved in type III 3-MGA, a neuro-ophthalmological syndrome consisting of early onset bilateral optic atrophy, later onset spasticity, extrapyramidal dysfunction, cognitive deficit, and abnormal urinary excretion of 3-methylglutaconic acid and 3-methylglutaric. The OPA3 gene contains two exons and its main transcript $(\sim 5 \mathrm{~kb})$ is ubiquitously expressed. It encodes a peptide composed of 179 amino acids displaying a putative mitochondrial $\mathrm{N}$-targeting signal sequence and a C-terminal coiled-coil domain. ${ }^{14}$ A proteomic study, done on mouse liver, has recently shown that the OPA3 protein is located in the inner mitochondrial membrane, ${ }^{18}$ but its function remains unknown. Only two mutations in the OPA3 gene have been reported so far (table 1). One of these-a homozygous splice site mutation (IVS1-1G>C) abolishing mRNA expression in fibroblastswas first found in Iraqi-Jewish patients with type III MGA. ${ }^{14}$ The other mutation, corresponding to a homozygous deletion in exon 2 (320-337del), resulting in deletion of six amino acids between residues 108 and 113, was reported in a
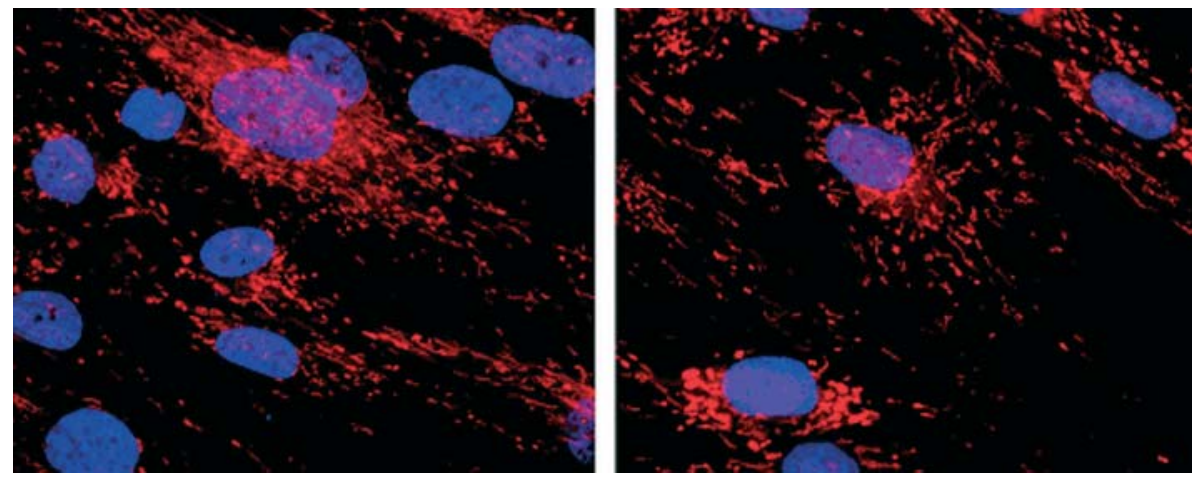

Figure 6 Mitochondrial network morphology. Fibroblasts from patient IV-2 (right); control fibroblasts (left). 


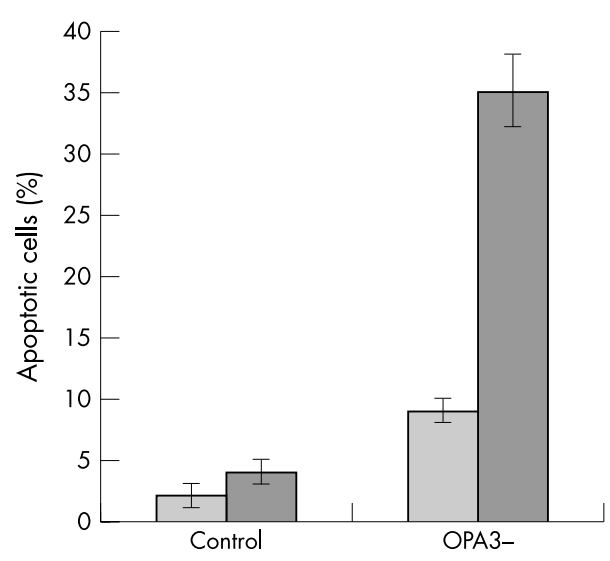

Figure 7 Staurosporin induced apoptosis in fibroblasts from patient IV2 versus control fibroblasts. Average values calculated from triplicate values obtained in the course of two independent experiments. Light grey, $50 \mathrm{mM}$ staurosporin; dark grey, $100 \mathrm{mM}$ staurosporin.

Kurdish-Turkish patient diagnosed with type IV MGA (3methylglutaconicaciduria, severe psychomotor retardation, and cerebellar dysgenesis). ${ }^{15}$

The novel two mutations of the OPA3 gene reported here were both heterozygous substitutions in exon 2. Several arguments support the pathogenicity of these mutations. First, both mutations segregated with the disease in each pedigree through different generations, and both were absent in a set of 400 control chromosomes. Second, both involved two strongly conserved residues in the OPA3 orthologs. Third, the mutation $277 \mathrm{G} \rightarrow \mathrm{A}$ increased the susceptibility to apoptosis induced by staurosporine in cultured fibroblasts. Thus different mutations in the OPA3 gene may be responsible for autosomal recessive or autosomal dominant optic atrophies. Homozygous mutations in OPA3 with loss of function lead to a severe multisystem disease with optic atrophy, whereas a heterozygous missense mutation results in a milder phenotype.

Interestingly, heterozygotic parents of patients affected by type III MGA are not affected by ADOAC, suggesting that haploinsufficiency of the OPA3 gene probably has milder consequences. Conversely, the effects of the missense mutations reported here are responsible for ADOAC in heterozygous patients. This would suggest a dominant negative effect of the G93S and Q105E OPA3 mutant alleles.

$O P A 1$ and OPA3 genes, responsible for ADOA and ADOAC respectively, are currently the only nuclear genes identified in dominantly inherited optic atrophy. Interestingly, three forms of hereditary optic atrophy for which the molecular bases are known involve either the mitochondrial DNA (LHON) or nuclear genes coding for mitochondrial proteins (OPAl and OPA3). Comparison between LHON, ADOA, and ADOAC also reveals similarities at the clinical and molecular levels, as follows.

First, in all three diseases, optic atrophy can be associated with more complex neurological signs such as dystonia or the Leigh-like syndrome in LHON, ${ }^{19}{ }^{20}$ deafness in $\mathrm{ADOA},{ }^{21}$ and mild extrapyramidal signs in ADOAC.

Second, all three diseases are caused by mutations in genes encoding proteins located in the inner mitochondrial membrane. LHON is mainly caused by mutation of mitochondrial DNA genes encoding respiratory chain complex I subunits; the OPAl gene encodes a protein anchored to the mitochondrial inner membrane facing the intermembrane space $^{6}$; and the OPA3 protein is also located in the mitochondrial inner membrane. ${ }^{18}$
Table 1 Mutations reported in the OPA3 gene

\begin{tabular}{|c|c|c|c|}
\hline Phenotype & Mutation & Inheritance & Reference \\
\hline MGA & IVS1-1G-C & Recessive & Anikster et al ${ }^{14}$ \\
\hline MGA & $320-337 \mathrm{del}$ & Recessive & Kleta ef al ${ }^{15}$ \\
\hline ADOAC & $277 G>A$ & Dominant & Present study \\
\hline ADOAC & $313 C>G$ & Dominant & Present study \\
\hline
\end{tabular}

Third, LHON, ADOA and ADOAC are all associated with painless optic atrophy without inflammation, consistent with an apoptotic mechanism, which could be common to the three disorders causing retinal ganglion cell death culminating in optic atrophy. Indeed, it has been shown that complex I plays a key role in the permeability of transition pores ${ }^{22}$ and that cells bearing mutations causing LHON are predisposed to apoptosis, ${ }^{23}{ }^{24}$ possibly because of increased production of reactive oxygen species. ${ }^{25}$ Similarly, it has been shown that the silencing of OPAl by RNA interference in HeLa cells leads to cytochrome c release and commits cells to apoptosis. ${ }^{26}$

Finally, increased susceptibility to the induction of apoptosis was also observed in our study in fibroblasts carrying the G93S mutation in OPA3. The further presence of cataract in ADAOC could also be explained by an apoptotic mechanism since there are several lines of evidence implicating apoptosis in cataractogenesis. ${ }^{27}$

\section{Conclusions}

The $O P A 3$ gene coding for a protein of unknown function of the mitochondrial inner membrane is responsible for both autosomal recessive and dominant optic atrophy. Further studies will be required to determine the role of the OPA3 protein in promoting increased cell death and to define the involvement of the OPA3 gene in other forms of optic atrophy.

\section{ACKNOWLEDGEMENTS}

We sincerely thank all the patients who have helped us in our research. We are grateful to Dr Jean-Paul Loemba for ophthalmological examination of patients from family 2, Yves Tourmen for bioinformatic searches, Philippe Bonnaud, Anne Coutolleau, Dominique Couturier, and Florence Fatih for excellent technical assistance, and Kanaya Malkani for critical reading and comments on the manuscript. The work was supported by INSERM, by GISInstitut des Maladies Rares, the University Hospital of Angers (CHU), the University of Angers, France, by Retina France, and the Association Française contre les Myopathies. CB was awarded a grant by the "Fondation pour la Recherche Médicale".

\section{Authors' affiliations}

P Reynier, P Amati-Bonneau, G Simard, Y Malthièry, INSERM E0018, and Laboratoire de Biochimie et Biologie Moléculaire, Centre Hospitalier Universitaire, Angers, France

C Verny, Département de Neurologie, Centre Hospitalier Universitaire, Angers, France

A Olichon, P Belenguer, G Lenaers, Laboratoire de Biologie Cellulaire et Moléculaire du Contrôle de la Prolifération UMR CNRS 5088, Université Paul Sabatier, Toulouse, France

F Malecaze, INSERM U 563, and Service d'Ophtalmologie, Centre Hospitalier Universitaire, Toulouse, France

H Dollfus, Service de Génétique Médicale, Centre Hospitalier Universitaire, Strasbourg, France

P Calvas, Service de Génétique Médicale, Centre Hospitalier Universitaire, Toulouse, France

D Bonneau, C Bonnemains, A Guichet, M C Malinge, J B Pelletier, Service de Génétique Médicale, Centre Hospitalier Universitaire, Angers, France

Conflicts of interest: none declared 
Correspondence to: $\operatorname{Dr} D$ Bonneau, Service de Génétique Médicale, CHU d'Angers, 4 rue Larrey, 49033 Angers cedex 01, France; dobonneau@chu-angers.fr

\section{REFERENCES}

1 Votruba M, Aijaz S, Moore AT. A review of primary hereditary optic neuropathies. J Inher Metab Dis 2003:26:209-27.

2 Alexander C, Votruba M, Pesch UE, Thiselton DL, Mayer S, Moore A, Rodriguez M, Kellner U, Leo-Kottler B, Auburger G, Bhattacharya SS, Wissinger $B$. OPA 1 , encoding a dynamin-related GTPase, is mutated in autosomal dominant optic atrophy linked to chromosome 3q28. Nat Genet 2000;26:211-15.

3 Delettre C, Lenaers G, Griffoin JM, Gigarel N, Lorenzo C, Belenguer P, Pelloquin L, Grosgeorge J, Turc-Carel C, Perret E, Astarie-Dequeker C, Lasquellec L, Arnaud B, Ducommun B, Kaplan J, Hamel CP. Nuclear gene OPA 1 , encoding a mitochondrial dynamin-related protein, is mutated in dominant optic atrophy. Nat Genet 2000;26:207-10.

4 Baris O, Delettre C, Amati-Bonneau P, Surget MO, Charlin JF, Catier A, Derieux L, Guyomard JL, Dollfus H, Jonveaux P, Ayuso C, Maumenee I, Lorenz B, Mohammed S, Tourmen Y, Bonneau D, Malthièry Y, Hamel C, Reynier P. Fourteen new OPA1 mutations in autosomal dominant optic atrophy including to de novo mutations in sporadic optic atrophy. Hum Mutat 2003;21:656

5 Misaka T, Miyashita T, Kubo Y. Primary structure of a dynamin-related mouse mitochondrial GTPase and its distribution in brain, subcellular localization and effect on mitochondrial morphology. J Biol Chem 2002;277:15834-42.

6 Olichon A, Emorine L, Descoin E, Pelloquin L, Brichese L, Gas N, Guillou E, Delettre C, Valette A, Hamel CP, Ducommun B, Lenaers G, Belenguer P. The human dynamin-related protein OPA 1 is anchored to the mitochondrial inner membrane facing the inter-membrane space. FEBS Lett 2002;523:171-6.

7 Kerrison JB, Arnould VJ, Ferraz Sallum JM, Vagefi MR, Barmada MM, Li Y, Zhu D, Maumenee $\mathrm{IH}$. Genetic heterogeneity of dominant optic atrophy, Kje type: identification of a second locus on chromosome 18q12.2-12.3. Arch Ophthalmol 1999:117:805-10.

8 Wallace DC, Singh G, Lott MT, Hodge JA, Schurr TG, Lezza AM, Elsas $\sqcup$, Nikoskelainen EK. Mitochondrial DNA mutation associated with Leber's hereditary optic neuropathy. Science 1988;242:1427-30.

9 Assink JJ, Tijmes NT, ten Brink JB, Oostra RJ, Riemslag FC, de Jong PT, Bergen AA. A gene for X-linked optic atrophy is closely linked to the Xp1 1.4 Xp1 1.2 region of the X chromosome. Am J Hum Genet 1997;61:934-9.

10 Barbet F, Gerber S, Hakiki S, Perrault I, Hanein S, Ducroq D, Tanguy G, Dufier JL, Munnich A, Rozet JM, Kaplan J. A first locus for isolated autosomal recessive optic atrophy (ROA1) maps to chromosome 8q. Eur J Hum Genet 2003;11:966-71.

11 Costeff H, Gadoth N, Apter N, Prialnic M, Savir H. A familial syndrome of infantile optic atrophy, movement disorder, and spastic paraplegia. Neurology 1989;39:595-7.

12 Costeff H, Elpeleg O, Apter N, Divry P, Gadoth N. 3-Methylglutaconic aciduria in "optic atrophy plus". Ann Neurol 1993;33:103-4.

13 Nystuen A, Costeff H, Elpeleg ON, Apter N, Bonne-Tamir B, Mohrenweiser H Haider N, Stone EM, Sheffield VC. Iraqi-Jewish kindreds with optic atrophy plus (3-methylglutaconic aciduria type3) demonstrate linkage disequilibrium with the CTG repeat in the $3^{\prime}$ untranslated region of the myotonic dystrophy protein kinase gene. Hum Mol Genet 1997;6:563-9.

14 Anikster Y, Kleta R, Shaag A, Gahl WA, Elpeleg O. Type III 3methylglutaconic aciduria loptic atrophy plus syndrome, or Costeff optic atrophy syndrome): identification of the OPA3 gene and its founder mutation in Iraqi Jews. Am J Hum Genet 2001;69:1218-24.

15 Kleta R, Skovby F, Christensen E, Rosenberg T, Gahl WA, Anikster Y. 3Methylglutaconic aciduria type III in a non-Iraqi-Jewish kindred: clinical and molecular findings. Mol Genet Metab 2002;76:201-6.

16 Garcin R, Raverdy P, Delthil S, Man HX, Chimenes H. Sur une affection hérédo-familiale associant cataracte, atrophie optique, signes extrapyramidaux et certains stigmates de la maladie de Friedreich. (Sa position nosologique par rapport au syndrome de Behr, au syndrome de MarinescoSjogren et à la maladie de Friedreich avec signes oculaires.). Rev Neurol 1961; 104:373-9.

17 Rustin P, Chretien D, Bourgeron T, Gerard B, Rötig A, Saudubray JM, Munnich A. Biochemical and molecular investigations in respiratory chain deficiencies Clin Chim Acta 1994;228:35-51.

18 Da Cruz S, Xenarios I, Langridge J, Vilbois F, Parone PA, Martinou JC Proteomic analysis of the mouse liver mitochondrial inner membrane. J Biol Chem 2003;278:41566-71.

19 Jun AS, Brown MD, Wallace DC. Mitochondrial DNA mutation at nucleotide pair 14459 of the NADH dehydrogenase subunit 6 gene associated with maternally inherited Leber hereditary optic neuropathy and dystonia. Proc Natl Acad Sci USA 1994;9:6206-10

20 Funalot B, Reynier P, Vighetto A, Ranoux D, Bonnefont JP, Godinot C, Malthièry Y, Mas JL. A Leigh-like mitochondrial encephalopathy complicating Leber's Hereditary Optic Neuropathy. Ann Neurol 2002;52:374-7.

21 Amati-Bonneau $P$, Odent $S$, Derrien $C$, Pasquier L, Malthièry $Y$, Reynier $P$, Bonneau $D$. The association of ADOA and moderate deafness may be due to the R445H mutation in the OPA 1 gene. Am J Ophthalmol 2003;136:1170-1.

22 Chauvin C, De Oliveira F, Ronot X, Mousseau M, Leverve X, Fontaine E. Rotenone inhibits the mitochondrial permeability transition-induced cell death in U937 and KB cells. J Biol Chem 2001;276:41394-8.

23 Danielson SR, Wong A, Carelli V, Martinuzzi A, Schapira AH, Cortopassi GA. Cells bearing mutations causing Leber's hereditary optic neuropathy are sensitized to Fas-induced apoptosis. J Biol Chem 2001;277:5810-15.

24 Ghelli A, Zanna C, Porcelli AM, Schapira AH, Martinuzzi A, Carelli V, Rugolo M. Leber's hereditary optic neuropathy (LHON) pathogenic mutations induce mitochondrial-dependent apoptotic death in transmitochondrial cells incubated with galactose medium. J Biol Chem 2002;278:4145-50.

25 Li N, Ragheb K, Lawler G, Sturgis J, Rajwa B, Melendez JA, Robinson JP. Mitochondrial complex I inhibitor rotenone induces apoptosis through enhancing mitochondrial reactive oxygen species production. J Biol Chem 2003;278:8516-25

26 Olichon A, Baricault L, Gas N, Guillou E, Valette A, Belenger P, Lenaers G. Loss of OPA1 perturbates the mitochondrial inner membrane structure and integrity, leading to cytochrome $\mathrm{c}$ release and apoptosis. J Biol Chem 2003;278:7743-6

27 Tempestini A, Schiavone N, Papucci L, Witort E, Lapucci A, Cutri M, Donnini $M$, Capaccioli S. The mechanisms of apoptosis in biology and medicine: a new focus for ophthalmology. Eur J Ophthalmol 2003;13/supp 3): $511-18$ 